Spreading the News 



\title{
SPREADING THE NEWS
}

The American Postal System from Franklin to Morse

\author{
Richard R. John
}

HARVARD UNIVERSITY PRESS

Cambridge, Massachusetts

London, England 


\section{To my family}

Copyright (C) 1995 by the President and Fellows of Harvard College All rights reserved

Printed in the United States of America

Second printing, 1998

First Harvard University Press paperback edition, 1998

Library of Congress Cataloging-in-Publication Data

John, Richard R., I959-

Spreading the news: the American postal system from Franklin to Morse / Richard R. John.

p. $\mathrm{cm}$.

Includes bibliographical references and index.

ISBN 0-674-83338-4 (cloth)

ISBN 0-674-83342-2 (pbk.)

I. Postal service-United States-History. I. Title.

HE6185.J634 I995

$383^{\prime} \cdot 4973-\mathrm{dc} 20$

95-20067 